\title{
A Rod-Shaped Virus Found in the Peony Ringspot
}

\author{
Moo Ung Chang, Yoji DOI and Kiyoshi YoRA* \\ 張 茂雄・土居養二・與良 清*: シャクヤク輪紋病 (peony ringspot) \\ で見出された桿状ウイルスについて
}

The peony ringspot, a virus disease characterized by leaf symptoms of yellow ringspots or yellow mosaic, has been reported from France, England, the United States, and Japan. The causal virus, the peony ringspot virus, is mechanically transmissible to tobacco, but more detailed nature of the virus has not been described (Smith, 1972) ${ }^{1)}$.

We detected a rod-shaped virus in Japanese peony (Paeonia albiflora Pall.) plants with leaf symptoms typical of the peony ringspot. The virus was always associated with the symptoms and could be transmitted mechanically. This indicates that the virus is the peony ringspot virus so far reported. In this note we describe some features of this virus.

The diseased peony plants (PlateI-1,4) were collected at the Ofuna Flower Center, Kanagawa Prefecture, in 1973, and at Tomiura, Chiba Prefecture, in 1975. Diseased peony leaves were macerated in $0.1 \mathrm{M}$ phosphate buffer ( $\mathrm{pH} 7.0$ ), and young seedlings of several plant species including Japanese peony were inoculated by carborundum method. Size of virus particles was determined from dip-preparations negatively stained with $2 \%$ PTA solution ( $\mathrm{pH} 6.0$ ). Small pieces of leaf tissue cut from the diseased plants, or from healthy plants as controls, were fixed in buffered $5 \%$ glutaraldehyde solution and postfixed in $2 \% \mathrm{OsO}_{4}$ solution. The pieces were then dehydrated through a graded series of ethanol and embedded in epoxy resin. Sections were stained with uranyl acetate followed by lead acetate before examination in an electron microscope (Hitachi HU-12).

Of plants inoculated with the virus, cowpea, French bean, broad bean, beet, Gomphrena globosa (Plate I-2). Chenopodium amaranticolor and tobacco (Bright Yellow) showed local lesions only, but soybean and Japanese peony were infected systemically, showing chlorotic or necrotic spots, sometimes mild mottling. Dippreparations from naturally or artificially infected plants alway showed the presence of rod-shaped particles of $25 \times 50-190 \mathrm{~nm}$ in size. The particles showed to have two modal lengths of 50-80 nm (short particles) and 170-190 nm (long particles) (Plate I-3). Such particles could not be found in healthy control plants.

In thin sections of leaves from the virus-infected plants, rod-shaped particles as stated above, although 50-190 nm long and ca. $20 \mathrm{~nm}$ wide in situ, were found in the cytoplasm and in xylem vessels. Long particles, 150-170 nm long, existed singly or as aggregates in side-by-side arrays in the cytoplasm. These particles were often positioned end-on to mitochondria (Plate I-6,8). Short particles, $50-80 \mathrm{~nm}$

\footnotetext{
* Laboratory of Plant Pathology, Faculty of Agriculture, University of Tokyo, Bunky-ku, Tokyo 113, Japan

東京大学農学部植物病理学研究室

1) Smith, K. M. (1972). In Textbook of Plant Virus Diseases (3rd ed.). Longman Group Ltd. London. p. 388 .
} 
long, appeared not to aggregate. They were orientated singly and randomly in the cytoplasm (Plate I-9). Sometimes both long and short particles were found to be scattered in xylem vessels of peony leaves (Plate I-7). In cross sections of the particle aggregates, individual particle showed the tubular structure (Plate I-5). It is worthy to note that the particles are closely associated with mitochondria, which showed some changes in their fine structures. At the early stage of infection, small aggregates of the particles, along with abnormal mitochondria, were found in the cytoplasm (Plate I-8, II-1,3). At the later stage of infection, the particles were hardly seen, but development of vacuoles (Plate II-1,2), small membranous sacs (Plate II-4), or membrane-encircled large areas containing fine thread-like materials (Plate II-6) were observed in mitochondria. Sometimes the membranous sacs showed characteristic rosette patterns (Plate II-4,5).

The virus described here was mechanically transmissible, but with difficulty. Electron microscopy of dip-preparations or thin sections always revealed the presence of the rod-shaped particles in the virus-infected plants and their absence in healthy control plants. From these results it is evident that the particles are those of the peony ringspot virus which causes the ringspot of Japanese peony.

The peony ringspot virus is very similar to $\mathrm{PRN}$ or $\mathrm{CAM} / \mathrm{DF}$ strain of the tobacco rattle virus in morphology and intracellular appearance of virus particles, abnormal fine structures of mitochondria, and host reactions ${ }^{2)}$.

These facts suggest strongly that the peony ringspot virus is a strain of the tobacco rattle virus.

\section{Explanation of plates}

Plate I 1. Chlorotic rings on leaf of Japanese peony.

2. Local chlorotic spot on leaf of Gomphrena globosa.

3. Rod-shaped particles in negatively stained dip-preparation from G. globosa leaf infected with peony ringspot virus. $(\times 60,000)$

4. Chlorotic ring pattern on leaf of Japanese peony.

5. Transverse view of rod-shaped particles in palisade parenchyma cell of G. globosa. $(\times 75,000)$

6. Side-by-side array of long particles in spongy parenchyma cell of G. globosa. $(\times 51,000)$

7. Long and short particles in xylem vessel of Japanese peony. $(\times 45,000)$

8. Virus particles and mitochondria showing abnormal fine structures in spongy parenchyma cell of Japanese peony. $(\times 21,400)$

9. Long and short particles (arrows) in the cytoplasm of palisade parenchyma cell of Japanese peony. $(\times 51.000)$

Plate II 1. A high magnification of Plate I-8. Note vacuole in mitochondria. $(\times 51,000)$

2. Abnormally enlarged mitochondria in the cytoplasm of mesophyll cell of beet. $(\times 32,000)$

3. Virus particles and abnormal mitochondria in spongy parenchyma cell of G. globosa. $(\times 34,000)$

$4,5,6$. Mitochondria with vacuole and membranous sacs in spongy parenchyma cell of Japanese peony. Note membranous sacs showing rosette pattern (arrows in 4 and 5$) \cdot(\times 45,000)$

Abbreviations used in Plate I and II $: \mathrm{cw}=$ cell wall $; \mathrm{m}=$ mitochondria $; \mathrm{p}=$ plastid $; \mathrm{v}=$ virus ; vac $=$ vacuole.

2) Harrison, B. D. et al. (1970). J. gen. Virol. $6: 127-140$. 
Plate I
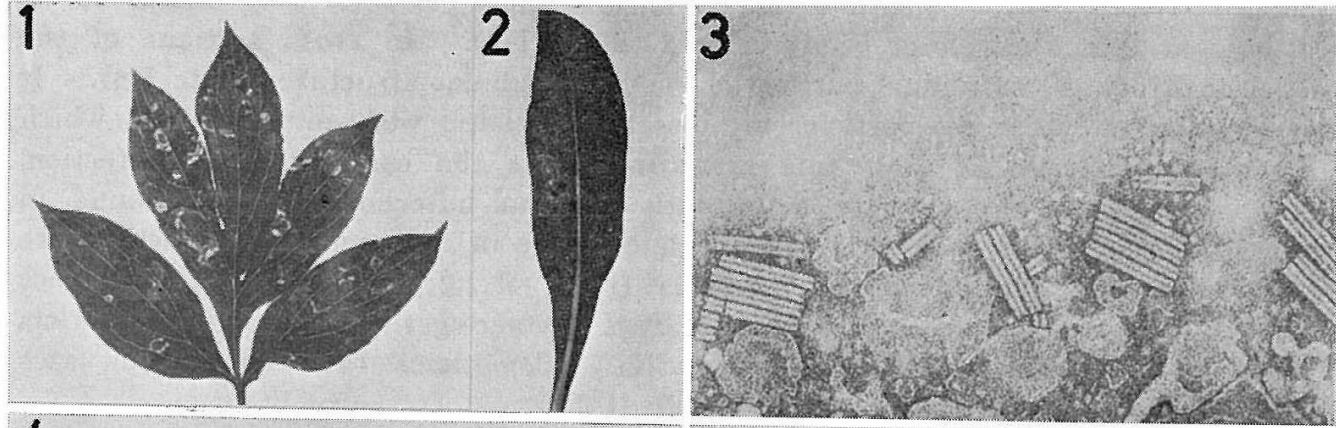

4
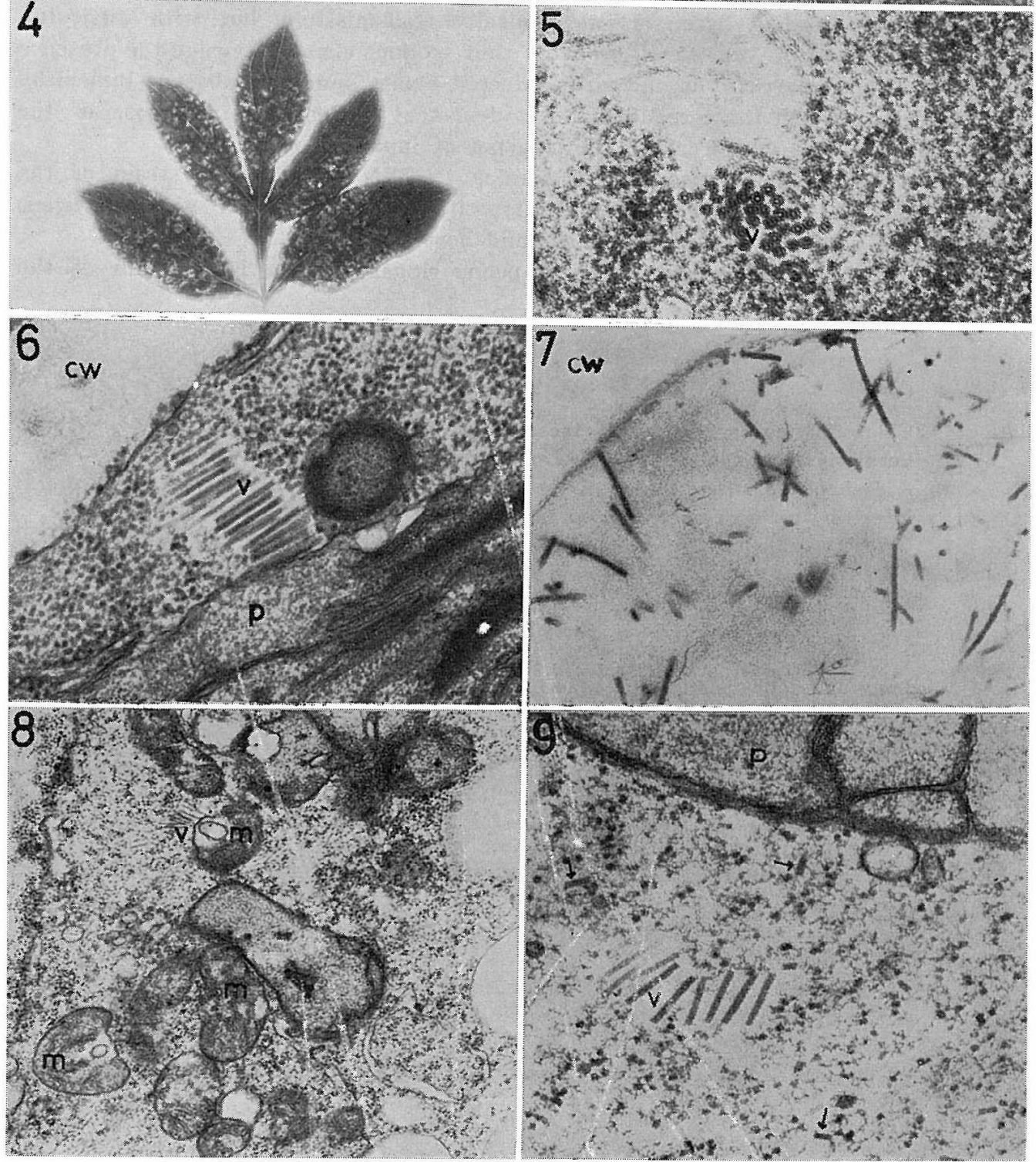
Plate II
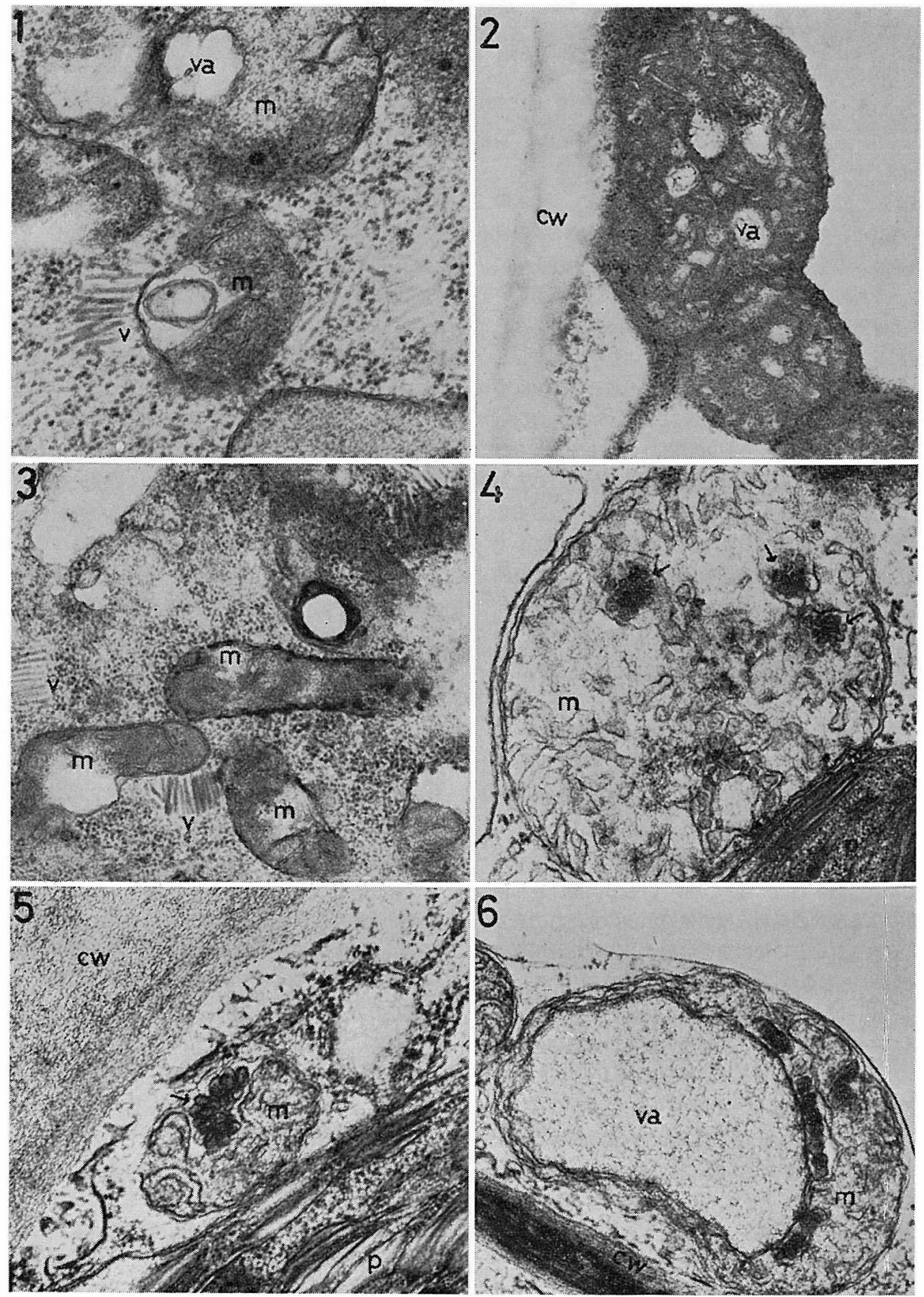